\title{
TRANSFORMATION PATTERNS OF PERIPHERAL VILLAGES UNDER URBANIZATION PRESSURE IN EGYPT
}

\author{
The case of El-Minya city \\ エジプトの市街化における都市周辺集落の変容パタンに関する研究 \\ ーミニヤ市におけるケーススタディー
}
Amany Nagy HAREEDY* and Atsushi DEGUCHI**
アマニーナギハリーディ, 出口敦

\begin{abstract}
In Egypt, peripheral villages encompassed within urbanized areas have recently undergone many transformations, becoming neither urban nor rural, but demonstrating features of both. This paper examines evidence of physical and socio-economic transformations occurring in two different neighborhoods of El-Minya City to find similarities and differences in their transformation typologies, transformation causes, and their negative impacts, to be used as a reference for future control strategies. Our analysis clarified 1) the physical transformations in urban fabric, blocks configuration, and building characteristics; and 2) the socio-economic transformation from a rural to urban style, but not to the degree of other city districts, including the loss of old local administrative units. Field observations with resident questionnaires revealed major negative impacts of transformations in: inadequacy of street networks for vehicle access, incompatibility of plots' decreased sizes with the application of planning laws, lack of maintenance for area physical components, diminishing main economic activities, and growing social conflicts. Our study results suggest the enhancing of such areas using special administrative units, through which partnerships between government and local residents can be used to solve these negative impacts and improve the environments of the respective areas.
\end{abstract}

Keywords: Sprawl, in situ Urbanization, Urban transformation, High-dense urbanized area, Egypt スプロール，市街化，都市変容，密集市街地，エジプト

\section{INTRODUCTION}

\subsection{Background and Research Issue}

In the last few decades, the continued growth of existing cities has dominated the urbanization process, specifically in developing countries ${ }^{1)}$. This process has resulted in significant pressure on peripheral rural areas, transforming them into new types of urban sites referred to by scholars variously as villagein-city ${ }^{2)}$, desakota ${ }^{3)}{ }^{4)}$, quasi-urban areas ${ }^{1}$, and encompassed villages ${ }^{5}$.

In Egypt, although "encompassed villages" provide good alternatives to conventional urbanization models dominated by rural-urban migration, they have been neglected from long-term planning models and studies. However, after seeing their problems exacerbate, these villages have been forced to change their administrative status to urban neighborhoods within adjoining cities without being properly incorporated into rural-urban development practices or being provided with suitable administrative units.

In light of these circumstances, such encompassed villages have undergone similar informal transformations to different degrees according to their location attributes, resulting in significant negative impacts on both their physical and socio-economic environments. However, continued negligence of these transformations and their related impacts will result in increased informal transformations, increased street network complications, the further deterioration of public property, conflicts in building characteristics, the growth of area densities, the loss of main economic activities, and decreased living standards with increased social conflict.

Overall, the new strategic plans, advanced by the planning authority in $2009^{6}$, have encompassed additional peripheral areas within the structure of Egyptian cities, showing that these areas have become a prominent feature of Egypt's urbanization. A review of these plans in addition to the limited published literature dealing with similar issues in the Greater Cairo ${ }^{7), 8)}$ revealed that the planning authorities still have not sufficiently addressed the issues related to the urbanization of such areas, nor have they put forth any practical scenarios for improving and dealing with them.

\subsection{Research Objectives}

Toward enhancing encompassed villages using effective strategies, this study aims first to examine the transformations of these villages and address their related issues. Based on a comparative analysis of two villages encompassed within El-Minya City, the study has three sub-objectives: 1) identifying the similarities and differences in the typologies of their physical characteristics and transformations, 2) investigating their socio-economic changes, and 3) clarifying the transformations' negative impacts on areas' environments.

\subsection{Research Methodology}

As a comparative study, this research compares the transformations that have occurred within two selected villages, El-Ekhsas and Kafrel-Mansourah, which were encompassed within El-Minya City in the early 1970s.

El-Minya (Fig.1), occupying an intermediate location between the Upper

\footnotetext{
* Doctoral Candidate, Graduate School of Human-Environment Studies, Kyushu University 九州大学大学院人間環境学府都市共生デザイン専攻 博士後期課程

** Prof., Faculty of Human-Environment Studies, Kyushu University, Dr. Eng. 九州大学大学院人間環境学研究院都市・建築学部門 教授・工博
} 
and Lower Egypt parts with an area of approximately $9.2 \mathrm{Km}^{2}$ and a population of about $239,000^{6}$, was selected mainly as: 1) the city is considered one of the medium-sized Egyptian cities that have recently experienced an excessive increase in their percentage of population change according to 2006 census 9), 10); and 2) the rural areas encompassed within the city's borders constitute about $40.2 \%$ of the city area, and $41.8 \%$ of its total population ${ }^{6}$.

Among the 13 rural areas that have been encompassed within the urbanized areas of El-Minya (Fig. 1), El-Ekhsas and Kafrel-Mansourah were selected for the reasons that they have definite geographic identities and borders, census classification as separate urban units, and a long history of encompassment in which a wide range of transformations can be detected (Table 1). Moreover, the two areas have different location attributes which should have different impacts on their respective degrees of transformation.

However, Chapter 2 draws an overview of the two study areas based on collected archived documents complemented by the information from the interviews with local government officers. It also includes secondary data analysis for Egyptian city planning and construction laws used until 2008.

Then, Chapter 3 shows the comparative analysis based on the field surveys conducted in El-Ekhsas from February to March 2009 and in KafrelMansourah from November 2009 to February 2010 as well as the comparison on the available maps of the study areas drawn in the two different ages; the late 1940s before encompassment and the late 2000s after encompassment. Thus, physical transformations after encompassment were traced through matching the collected maps and the results of the field surveys.

Chapter 4 analyzes on the socio-economic characteristics of each target area by statistical processing of consecutive census. In Chapter 5, the socio-economic characteristics and opinions of residents regarding area's transformations based on the questionnaire tests for residents. Particularly, the analysis focuses on the negative impacts and factors of such transformations. The questionnaire tests were conducted to random samples of 100 household heads in each area; 40 samples in the old core A, and 30 in the expansion parts of $\mathrm{B}$ and $\mathrm{C}^{* 11}$. As a result, the collection rate was $89 \%$ in El-Ekhsas and $86 \%$ in Kafrel-Mansourah, and the validity of data was checked by overview of the unbiased attributes of respondents as shown in Table 2. Finally, comparing the collected data, we identified main similarities and differences in characteristics, transformations, related problems, and leading influences in these areas using correlations, tables, indicative maps, photos, and diagrams.

\section{OUTLINE OF STUDY AREAS AND PLANNING LAWS}

\subsection{Location Attributes}

El-Ekhsas (EE) and Kafrel-Mansourah (KM), both of which were converted into city neighborhoods of El-Minya in the early 1970s, have different location attributes that were drawn as follows.

Referring to Fig. 1 and 2, EE, which lies on the northern periphery of the city, with 20 acres of built-up area and a population of 3,621 according to the 2006 census $^{9}$, is characterized by its a) close proximity to the affluent formal neighborhoods of Shalabi (to the west) and Ard-Sultan (to the south), and b) confined location, bordered by the Nile River on the east and a cotton ginning factory on the north and west.

On the other hand, KM (Fig. 3), which lies on the southwestern periphery of the city, with 66 acres of built-up area and a population of 25,019 according to the 2006 census ${ }^{9)}$, is characterized by its a) long distance from the city's formal districts and proximity to the informal areas of Abo-Helal, the southern division (to the east), and the hamlets of Jaheen, El-Khashabah, El-Mosas, and Taha-Elsabe (to the north, Fig. 1), and b) open location to the west and south because of the vast agricultural lands surrounding the area.

\subsection{Chronological Growth}

Early Egyptian rural settlements almost occupied appropriate hills to be safe from the Nile flooding threats (Fig. 4). The efforts to control the Nile flooding which started by Mohammed Ali, in the beginning of the 19th century, followed by the construction of an irrigation system using a number of irrigation dams, drifts, and finally the construction of the High Dam in the late 1960s all helped in completely transform the land irrigation from a seasonal to
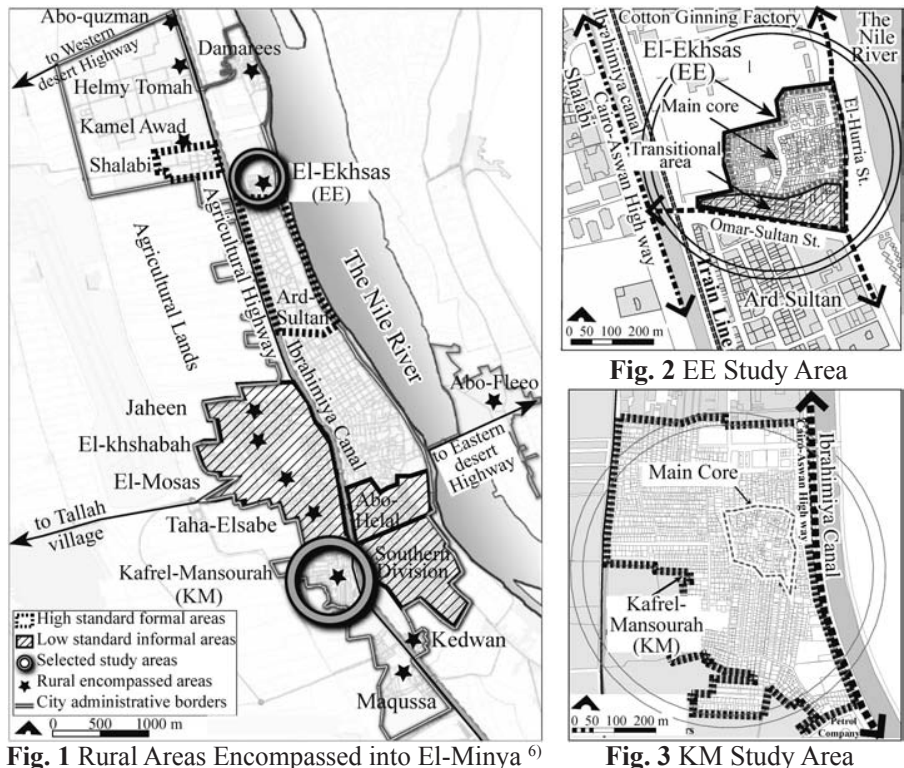

Table 1 Rural Areas Encompassed into El-Minya City

\begin{tabular}{|c|c|c|c|c|c|c|}
\hline \multirow{2}{*}{\multicolumn{2}{|c|}{$\begin{array}{l}\text { Encompassed rural areas } \\
\text { into El-Minya City }\end{array}$}} & \multicolumn{2}{|c|}{$\begin{array}{c}\text { Geographic Identity/ } \\
\text { Borders }\end{array}$} & \multicolumn{2}{|c|}{ Periodic census } & $\begin{array}{c}\text { History of } \\
\text { encompassment }\end{array}$ \\
\hline & & Definite & Indefinite & Available & Unavailable & e Long Short \\
\hline \multirow{4}{*}{$\begin{array}{c}\text { Before } \\
\text { year } \\
2000\end{array}$} & El-Ekhsas village (EE) & $\bullet$ & & - & & $\bullet$ \\
\hline & $\begin{array}{l}\text { Expanded western hamlets of } \\
\text { re (Ezbet) Jaheen, El-Khashabah, } \\
\text { El-Mosas, Taha-El-Sabe }\end{array}$ & & - & & - & - \\
\hline & $0 \begin{array}{l}\text { Small confined hamlets of } \\
\text { (Ezbet)Abo-quzman, Helmy- } \\
\text { Tomah, Kamel Awad }\end{array}$ & - & & & - & - \\
\hline & Kafrel-Mansourah village (KM & $\cdot$ & & - & & $\bullet$ \\
\hline \multirow{3}{*}{\begin{tabular}{|l|} 
After \\
year \\
2000
\end{tabular}} & r Damare & - & & - & & - \\
\hline & & & - & & $\bullet$ & \\
\hline & $0 \begin{array}{l}\text { Maqussa village } \\
\text { Kedwan hamlet }\end{array}$ & $\div$ & & - & & $\div$ \\
\hline
\end{tabular}

Table 2 Attributes of Questionnaire Test Respondents

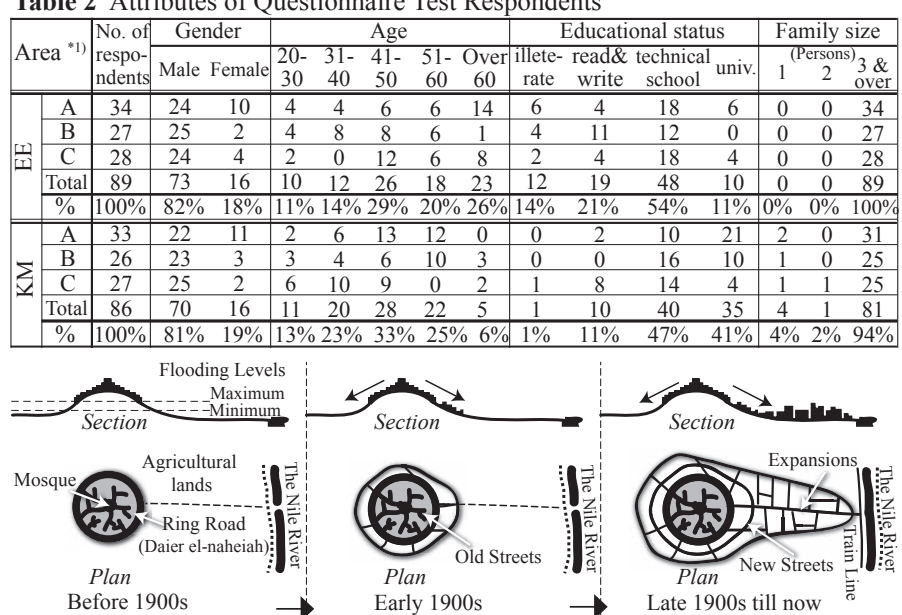

Fig. 4 Evolution of Early Rural Settlements and Controlling the Nile Flooding ${ }^{11)}$ 
permanent system. Accordingly, these efforts, which were consolidated by the evolution of travel ways, encouraged the rural settlements living on the hills to spread down on the lower flat agricultural lands safely ${ }^{11)}$.

Like most of old settlements of Egyptian cities, the main urban area of El-Minya was expanded to the north, west, and south directions encroaching on its agricultural peripheries until abutting its peripheral villages (Fig. 5). Consequently, both EE and $\mathrm{KM}$ villages were annexed within the administrative borders of the city in early $1970 \mathrm{~s}$

However, EE and KM historically began before the 1900s as small, builtup areas (Part A) (Fig. 6, 7), which included light structured houses penetrated by many infill areas. The residents were mainly villagers who worked in the surrounding agricultural lands. The two villages expanded gradually until the late 1960s, resulting in the construction of Part B. The expansion of EE was mainly encouraged by the construction of the nearby cotton ginning factory, which employed more than $50 \%$ of its villagers once it began operation. The expansion of KM, on the other hand, was encouraged by its vast surrounding, privately owned agricultural lands. Subsequently, both villages continued their expansions to form Part C informally.

\subsection{Planning and Construction Regulations}

Until late 2008, the villages, which were encompassed and converted into urban neighborhoods within their mother cities' borders, have officially been under the jurisdiction of City Planning Law No. $3 / 1982^{12)}$ and Construction Law No.106/ $1976^{13)}$. However, a lot of building activities occurred in these areas against the main stipulations in these laws regarding;

a) Minimum road width: No permission for constructions facing a road of less than 6 meter width. Otherwise, the building should be set back by a distance of half the difference between the required 6 meters and the original street width.

b) Land subdivisions: Any plot of land to be subdivided into more than 2 sub-plots should meet the following requirements; $1 / 3$ of the plot area should be allocated for roads, squares, and public parks. Each piece of the divided

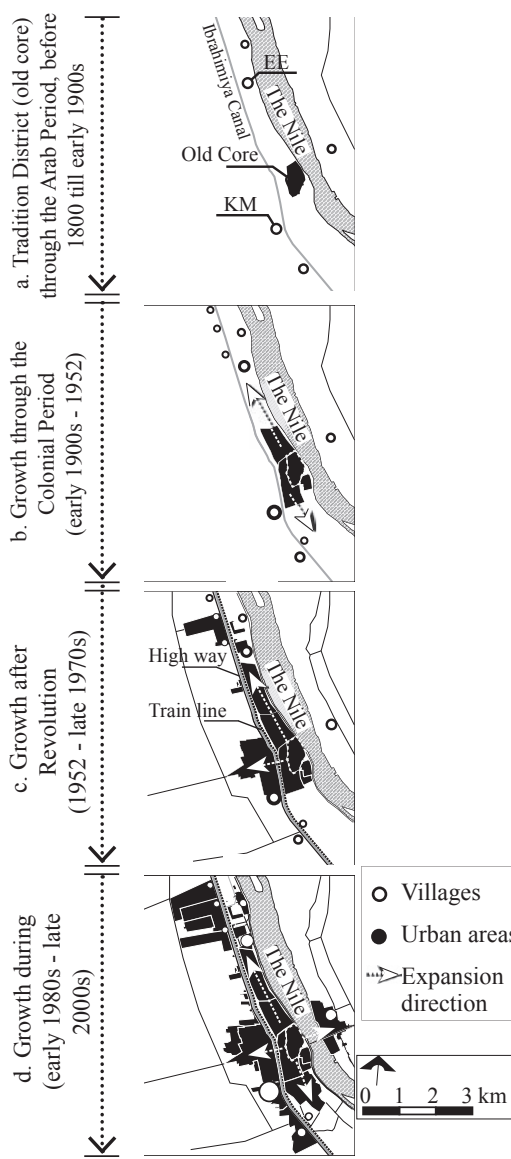

Fig. 5 Chronological Urban Growth of El-Minya City $(1800 s-2000 s)^{10)}$

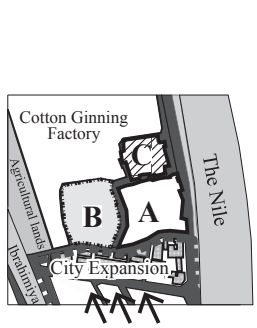

$0 \quad 100 \quad 200 \mathrm{~m}$

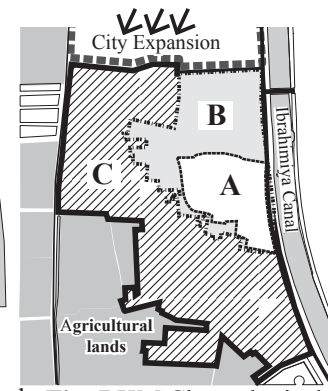

Fig. 6 EE Chronological Fig. 7 KM Chronological Growth *2)

Table 3 Urban Fabric Patterns of the Different Growth Stages in EE and KM

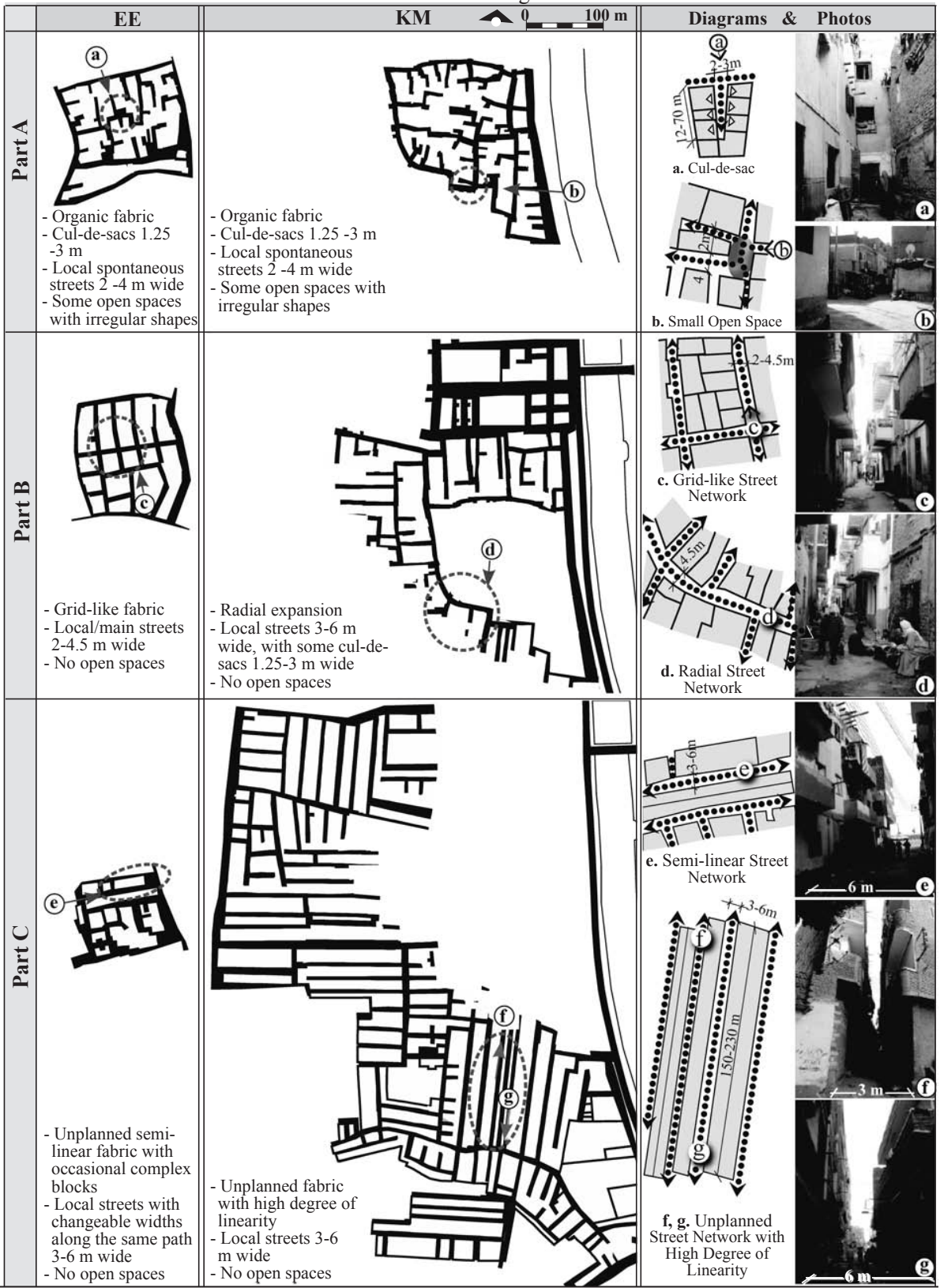


plot should face at least one road with no less than 6 meter width. The enclosed areas of buildings should not exceed $60 \%$ of the plot, and the open built areas such as terraces, stairs, and building entrances may only extend for $10 \%$ of a building's enclosed area. This is with possibility of exceptions in exceeding this percentage in some cases according to the discretion of local authorities.

c) Construction characteristics: Building height should not exceed 1.5 times the facing road width, with maximum height of 36 meters with exceptions in critical cases in special city areas. The building owners should provide a sufficient number of elevators for buildings whose top floor exceeds 16 meters from ground level with the sufficient number and area of parking spaces. Any additional constructions, changes, or facade paintings are not allowed until the permission is obtained from the local authority.

\section{PHYSICAL CHARACTERISTICS AND TRANSFORMATIONS}

\subsection{Characteristics of Original Rural Part A}

The old cores of these settlements (Part A) (Table 3), were characterized by their organic urban fabric including narrow winding streets (1-4 m wide), cul-de-sacs, and small open spaces that efficiently afforded social communication among residents. The blocks were shaped by irregular complex configurations due to the random, unplanned construction that occurred on private property. The original buildings were built from mud walls and wooden ceilings, with 1 or 2 floors serving for just one family.

\subsection{Physical Transformations (Similarities and Differences)}

Similar and different transformations of the two target areas practiced following the encompassment period can be traced through their urban expansions (Parts B and C), and also through the adaptations made to old neighborhood cores (Part A) as follows.

\section{a) Urban Fabric Transformation}

The new expansions of the target areas transformed generally into a more linear urban fabric, with random linear street networks (3-6 m wide) (Table 3). These expansions, Parts B and C, despite their flexible accessibility, retain the narrow street widths characteristic of the old cores. Moreover, they lack open spaces, which were typically available in the old cores. This problem resulted in residents using the public street space for socially interaction, children's play, and even for breeding animals, thereby overloading street capacities and obstructing vehicle access.

On the other hand, differences in the transformations can be seen in Part B of each area. Part B of EE was developed in a grid-like pattern with streets 2-4.5 m wide, while that of $\mathrm{KM}$ was developed in the form of radial expansion with streets 1.25-3 m wide using occasional cul-desacs. Furthermore, the degree of linearity in the expanded Part C of KM is much higher than that of EE, because of the presence of vast agricultural lands surrounding KM encouraging such linear expansion. In contrast, the confined space of EE stopped expanding after a certain degree.

In total, less than $1 \%$ of the total buildings in each area were issued legal construction permits after encompassment ${ }^{14)}$. This fact indicates the degree to which informality has shaped the urban fabric of such areas, even after their conversion into urban neighborhoods within their adjoining city. b) Transforming of Block Configuration

Original blocks of the old cores (Part A) passed through adaptation processes
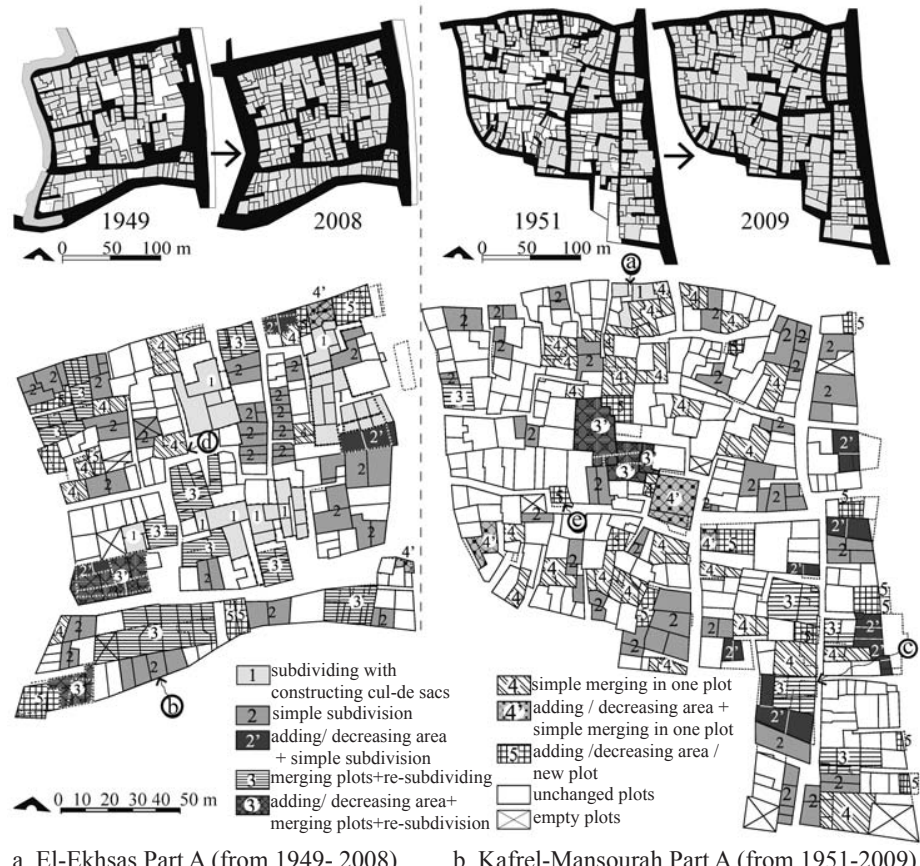

a. El-Ekhsas Part A (from 1949- 2008) $\quad$ b. Kafrel-Mansourah Part A (from 1951-2009)

Fig. 8 Physical Transformation Types in Plot Level in Two Study Areas

Table 4 Patterns of Plot Transformation in Part A of Two Areas

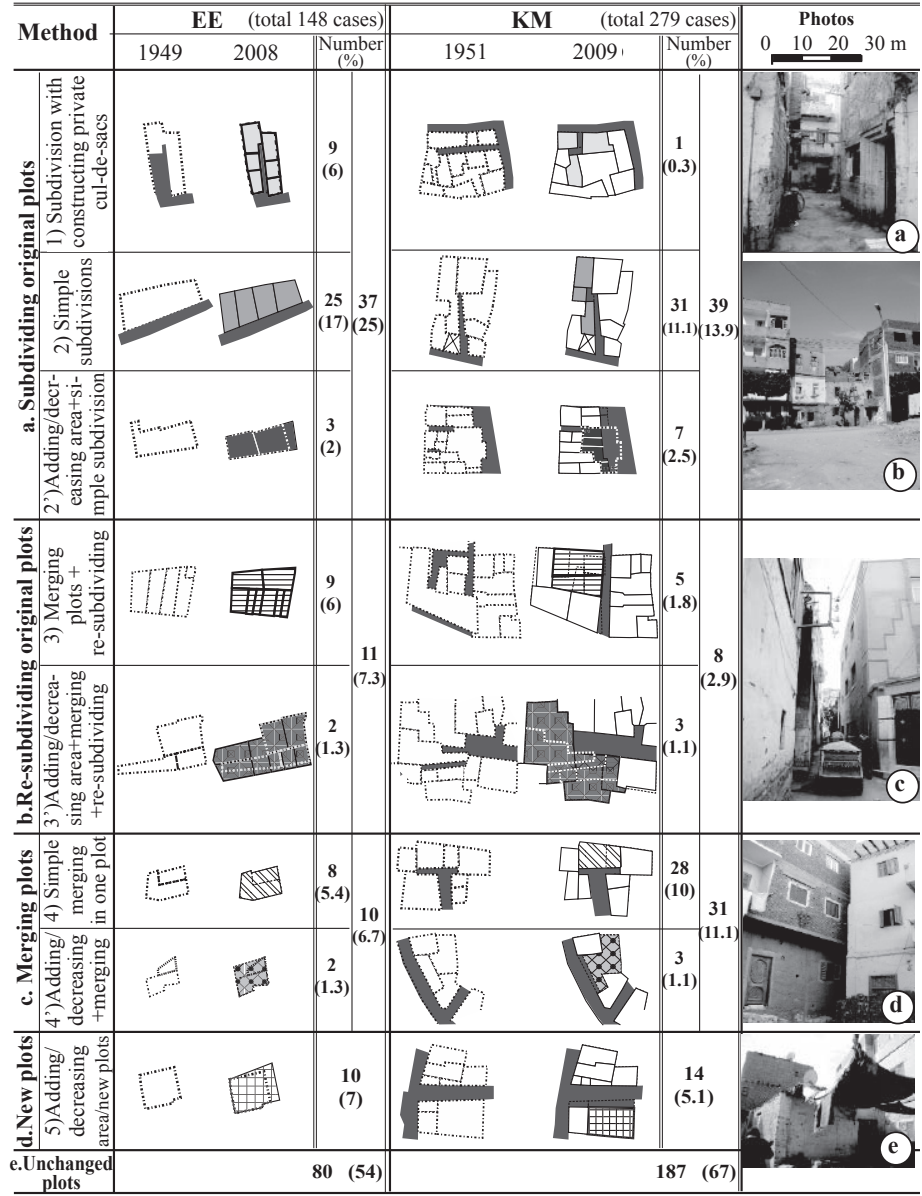

that can be attributed mainly to property inheritance practices. About $76 \%$, and $92 \%$ of the total respondents in Part A of EE and KM, respectively, mentioned that they gained their properties by inheritance. By comparing the maps of Part A in early 1950s and late 2000s (Fig. 8) and counting up a group of plots that was merged into one plot as one case, and also a plot that was divided into 
multi-plots as one case, 148 cases in EE and 279 cases in KM were found out (Table 4). Apart from the cases of unchanged plot in Part A (54\% and 67\% of the total cases in EE and KM, respectively), the cases could be classified into eight patterns that can be further grouped into four major patterns (Table 4); subdividing original plots ( $25 \%$ and $14 \%$ of total cases in EE and $\mathrm{KM}$, respectively); re-subdividing plots after merging a set of original plots (7\% and $3 \%)$; merging original plots with cutting or adding certain areas $(7 \%$ and $11 \%$ ); and finally, the formation of new plots or decreasing/expanding original plot area ( $7 \%$ and $5 \%)$.

Moreover, new blocks of the expanded parts (B and C) show a trend of transformation from a complex to a much simpler linear configuration, with semi-rectangular shapes along with occasional complex blocks formed in both areas. This linearity was acquired through subdivisions following the existing linear irrigation system and the boundaries of agricultural land holdings (Fig. 9). The transformation process started by villagers dividing their land into simple, semi-rectangular blocks (15-25 m wide), filling up the narrow irrigation canals (1-3 $\mathrm{m}$ wide) to be used as streets, and then subdividing the blocks into smaller lots ranging between 60 and $100 \mathrm{~m}^{2}$. Finally, the new lots were built, either by the original villagers, their successors, or new developers.

As for differences in block transformation, these are traced and explained in relation to their location attributes in section 2.1. The degree of block linearity in $\mathrm{KM}$, for example, is higher due to the vast surrounding, privately owned agricultural lands (Fig. 10). Hence, block length in the expanded parts of KM reached $190 \mathrm{~m}$ in some locations, while in EE no block exceeded $110 \mathrm{~m}$. Moreover, the degree of plot adaptation in EE was found to be much higher, as evidenced by the adaptation of $45 \%$ of its total locations in Part A, compared with just 33\% in KM (Table 4). Actually, the close location of EE to the affluent formal neighborhoods, its confined land, and the growing need for housing all contributed to increases in its land prices, leading residents to engage in more adaptation processes for economic benefit. Accordingly, small plots with areas less than $50 \mathrm{~m}^{2}$ were created in $\mathrm{EE}$ at a rate (of $46.3 \%$ of total plots) higher than what was witnessed in KM (27.5\%) (Table 5). In contrast, $\mathrm{KM}$, because of its close location to informal neighbourhoods and the wide range of surrounding land, experienced a greater increase in plot area.

However, the sequential informal practices of block subdivision and plot adaptation led to an overall decrease in plot area, representing a critical problem for residents when faced with having to apply construction laws; this was noted by $64 \%$ and $58 \%$ of total respondents in $\mathrm{EE}$ and $\mathrm{KM}$, respectively.

\section{c) Building Characteristic Transformation}

To illustrate the similar and different trends of building transformations, in terms of height, construction materials, and architectural design, we performed a comparative analysis of two building groups in both areas: buildings that had been built before the encompassment period (pre-1970) (46\% and $18 \%$ of the total buildings in EE and KM, respectively), and those built during the period (54\% and $82 \%$, respectively) (Fig. 11.a).

First, regarding building height,we found that the two areas still maintain high percentages of buildings having only 1 or 2 floors ( $31 \%$ and $55 \%$ of the total buildings in EE and KM, respectively) (Fig. 11.b). Nonetheless, Table 5 shows that both areas share a trend toward a decrease in the number of lowrise buildings ( 1 or 2 floors) during the encompassment period (a shift from

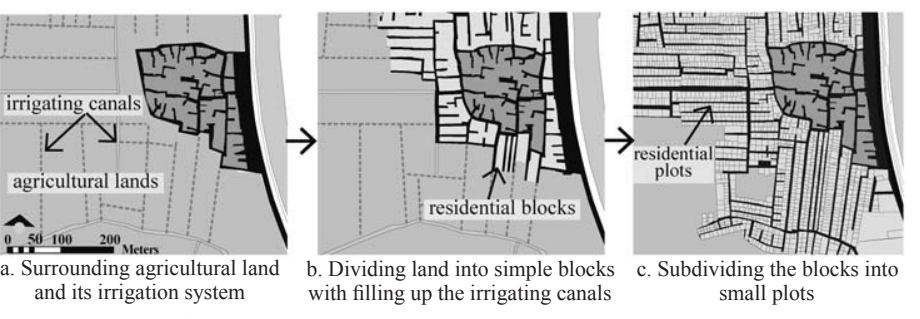

Fig. 9 Land Transformation Process and the Impact of Irrigation System on Block Configuration in the New Expansions (in KM)

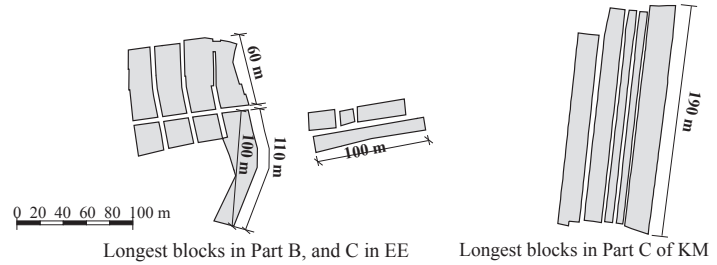

Fig. 10 Different Degrees of Block Linearity

Table 5 Percentages of Plot Area in Parts A, B, C of the Two Study Areas

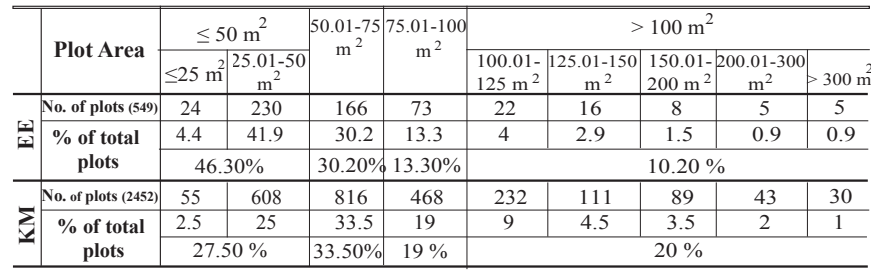
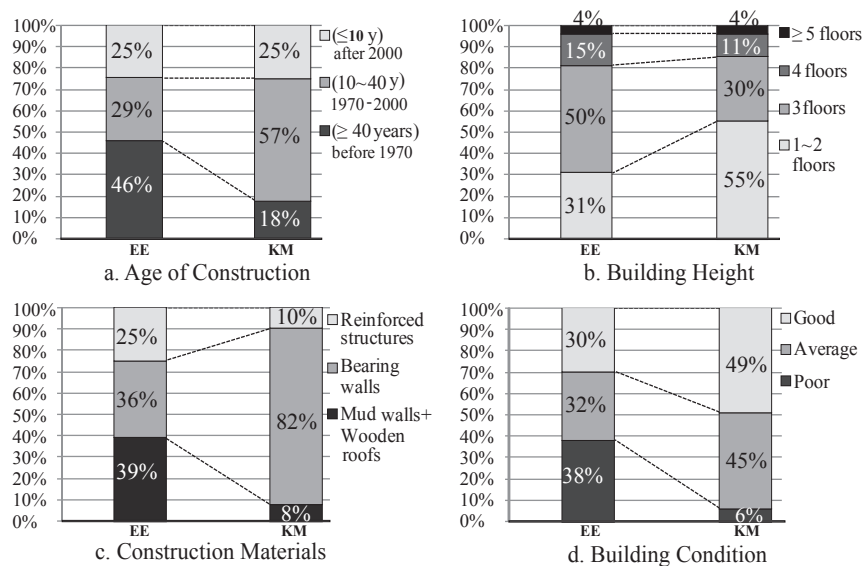

b. Building Height

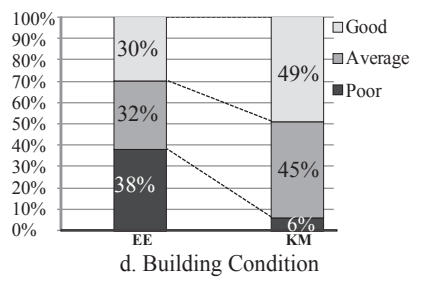

Fig. 11 Comparison of Building Characteristics in the Two Study Areas

$41 \%$ to $22 \%$ of the total buildings in EE, and a shift from $84 \%$ to $49.5 \%$ in $\mathrm{KM}$ ); and a trend toward an increase in the number of high-rise buildings (more than 3 floors), from $8 \%$ to $29 \%$ in EE, and from $1 \%$ to $17.5 \%$ in $\mathrm{KM}$.

Second, a comparison of construction materials (Fig. 11.c) and building age (Fig. 11.a) shows the prevalence of using primitive local materials in the past, while sequential replacement in some buildings occurred using new materials over time. A high percentage of EE buildings were built before the encompassment $(46 \%)$; thence a high percentage of buildings were constructed using mud walls and wooden ceilings (39\%). Similarly, just 18\% of KM buildings were constructed before the encompassment, and thus a low percentage of its buildings $(8 \%)$ have mud walls and wooden ceilings. Furthermore, both areas were found to have high percentages of bearing wall constructions ( $36 \%$ and $82 \%$, respectively), which is explained by resident preferences, specifically in KM, because such structures were of better quality than those made of primitive materials, and cheaper than those made 
Table 6 Trends of Change in Building Characteristics in the Two Study Areas

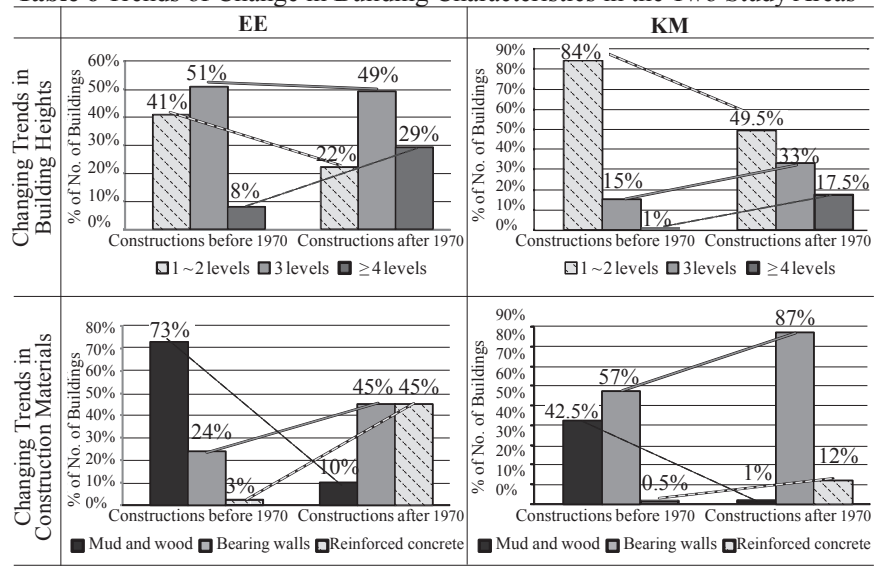

of reinforced concrete. However, Table 6 shows a similar trend in both areas toward decreasing percentages of buildings using such primitive materials during the encompassment period (from $73 \%$ to $10 \%$ in EE, and from $42.5 \%$ to $1 \%$ in $\mathrm{KM}$ ); increasing percentages of bearing wall constructions (from $24 \%$ to $48 \%$, and from $57 \%$ to $87 \%$, respectively); and increasing percentages of reinforced structures (from $3 \%$ to $45 \%$, and from $0.5 \%$ to $12 \%$, respectively).

Third, regarding building design, old rural houses (Fig. 12.a) that were originally inhabited by mainly one family, including a production unit (e.g., a barn unit for animal and bird breeding) and a courtyard for family social activities, changed to a more urban style. Such changes, including a shift toward more apartment buildings (Fig. 12.b) designed for housing multiple and extended families, excluded barns and traditional courtyards from their design, reducing the possibility of keeping houses as productive entities ${ }^{11)}$. Our survey results supported these findings, showing that even residents who still work in rural activities redesigned their houses and thus must keep their animals in the public spaces of the streets adjoining their property (Fig. 12.c).

On the other hand, our analysis showed different changing trends in both target areas in the percentages of buildings with three floors. EE witnessed a slight decrease from $51 \%$ to $49 \%$, whereas $\mathrm{KM}$ witnessed an increase from $15 \%$ to $33 \%$. Moreover, EE showed a higher degree of increased use of reinforced structures than KM, because of the higher degree of socioeconomic mobilization of the EE area, as afforded by its location attributes.

All in all, building conditions (Fig. 11.d) showed high percentages of good (30\% of total buildings in EE; $49 \%$ in $\mathrm{KM})$ and average conditioned buildings ( $32 \%$ and $45 \%$ ), illustrating the sequential transformations that were accelerated in these areas by modernization, natural growth, increased needs for housing, and the dominance of private property ownership.

\section{SOCIO-ECONOMIC CHARACTERISTICS AND TRANSFORMATION}

The target villages also experienced socio-economic transformations which can be analyzed in the following terms.

\subsection{Educational Status}

Analyzing the residents' educational status of the target areas according to the last four censuses ${ }^{9)}$ shows significant changes to more educated (Fig.

13), but they still maintained their status as having the highest percentages of illiterate and primary-school educated residents, and the lowest percentages of technical-school and university graduates compared with residents of other city divisions, regarding the 2006 census ${ }^{9)}$ (Fig. 14, 15). Division 4 (D4) has
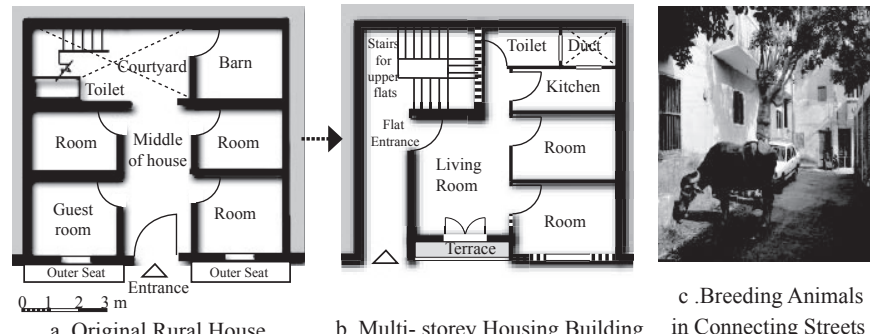

c.Breeding Animals a. Original Rural House bulti- storey Housing Building in Connecting Streets Fig. 12 Design Transformation of Residential Buildings

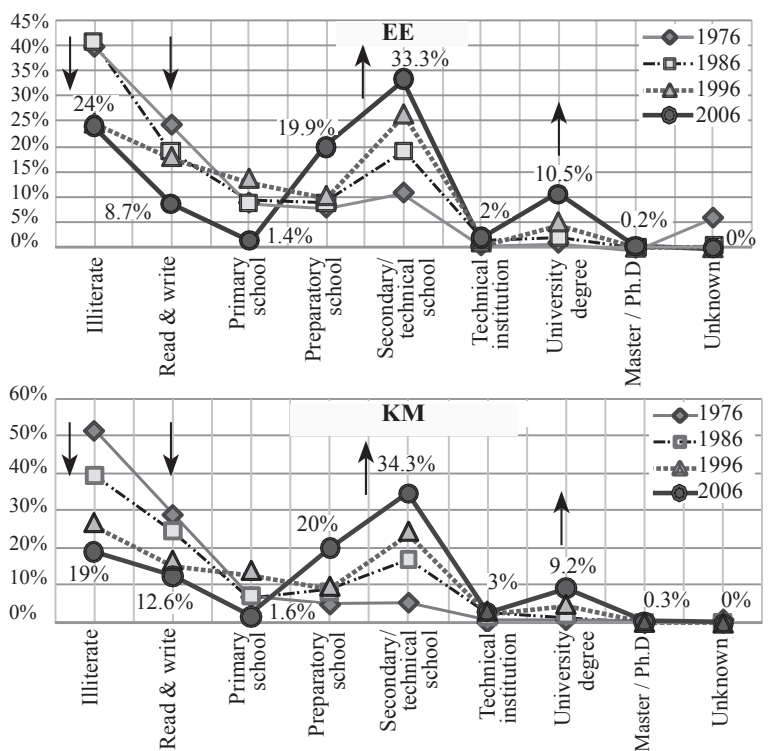

Fig. 13 Trends of Change in Educational Status in EE and $\mathrm{KM}^{\text {9) }}$

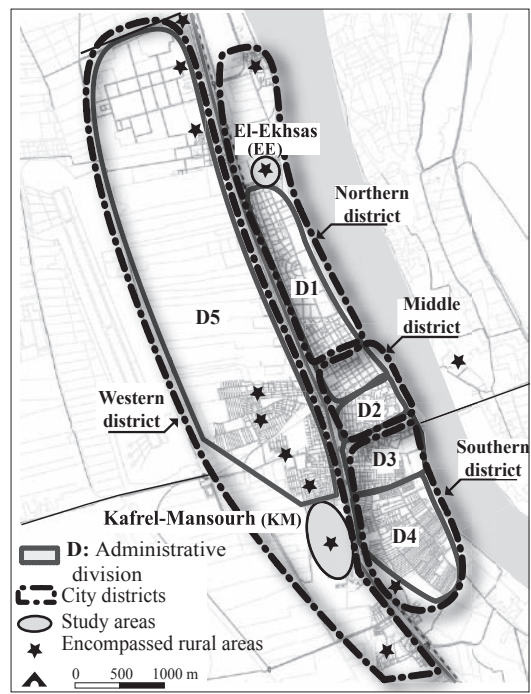

Fig. 14 El-Minya Administrative Divisions, and Districts ${ }^{14),}$,

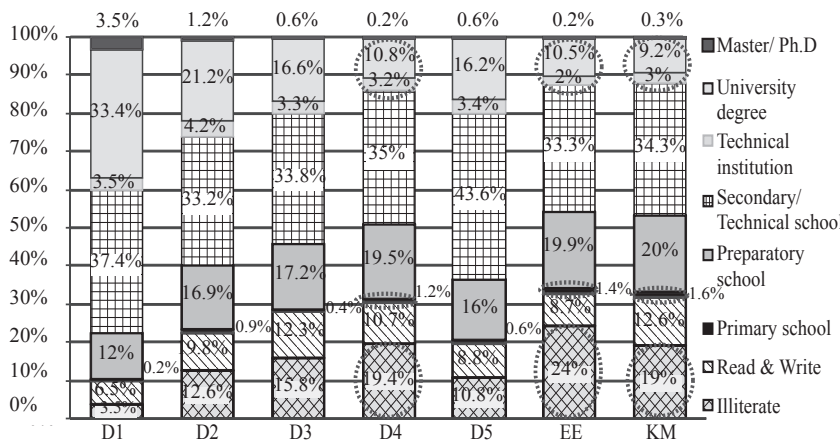

Fig. 15 Ratios of Resident Educational Status in EE and KM Compared with Other City Divisions ${ }^{9)}$ 
similar characteristics with such areas, as an informal area.

\subsection{Social Traditions}

The social structure of these areas was originally distinguished by their dependence on a kin-bound society and folk-sustained social systems. With the political and economic changes after the 1952 revolution, rural villages drastically opened up to modern lifestyle practices. Some residents migrated, and were soon replaced by newcomers searching for affordable housing close to city jobs. Thus, the areas' original relationships gradually became weaker. However, resident questionnaire test showed traces of these traditional kin relations. Moreover, we observed that some residents still maintain some rural traditions, such as using the public spaces of streets for social activities, such as neighbor gathering, children's playing, street vending, and sometimes even animals breeding in front of their houses, as mentioned earlier (Fig. 16).

\subsection{Security and Local Administrative System}

These areas were previously administered by a respected leader, who was the head of the biggest family in the village (Omda), while being assisted by the head of the second biggest family (Shikh el-balad), and a few local guards (Khafar). This local administrative unit was supported by the central government. Subsequently, by changing the administrative status to urban neighborhood, these areas lost such units and came under city jurisdiction. On the other hand, according to local administrative law no. 43 (1979) ${ }^{15}$, every planning level (Governorate, Province, City, District, Village) had to have two local administrative councils: a LPC local popular council whose members were determined by election, and a LEC local executive council whose members were officially appointed (Fig. 17). In reality most mediumsized and small cities, such as El-Minya, do not have such councils at the district level. Hence, the city's LPC and LEC, including branches that cover city districts, became the lowest level in the city local governing system.

As for the encompassed villages, we found that they were mostly annexed administratively within neighboring administrative divisions, even in cases when they differed greatly in their respective characteristics, to form heterogeneous districts. In El-Minya, EE was added to Division Number One, the area of Ard Sultan with the highest socio-economic status, forming the northern district; similarly, KM was added to Division Number Five, forming the western district (Fig. 14). Furthermore, in absence of popular councils at the district level, the representative parties of such encompassed villages, that should best represent resident needs, became very weak at the city level. Owing to this, informality was common practice in such areas, with residents sometimes not allowing the interference of the police in quelling riots, and sometimes even hindering the judicial execution of laws.

\subsection{Economic Activities}

The economic activities in these areas change from agricultural to almost completely non-agricultural, differing from area to area according to the dominant activities in their mother cities. Analyzing the economic activities derived from the last three censuses ${ }^{9)}$, the two study areas showed significant decreasing trends in their agricultural and manufacturing activities (Fig. 18). Furthermore, a comparison with other city divisions showed that EE and KM still maintain the lowest percentages of residents working in community and public services (Fig. 19) despite increases in their percentages than last decades (Fig. 18). Indeed, the erosion of agricultural lands for housing needs,



Fig. 16 Children Playing and Street Vendors Occupying Local Streets
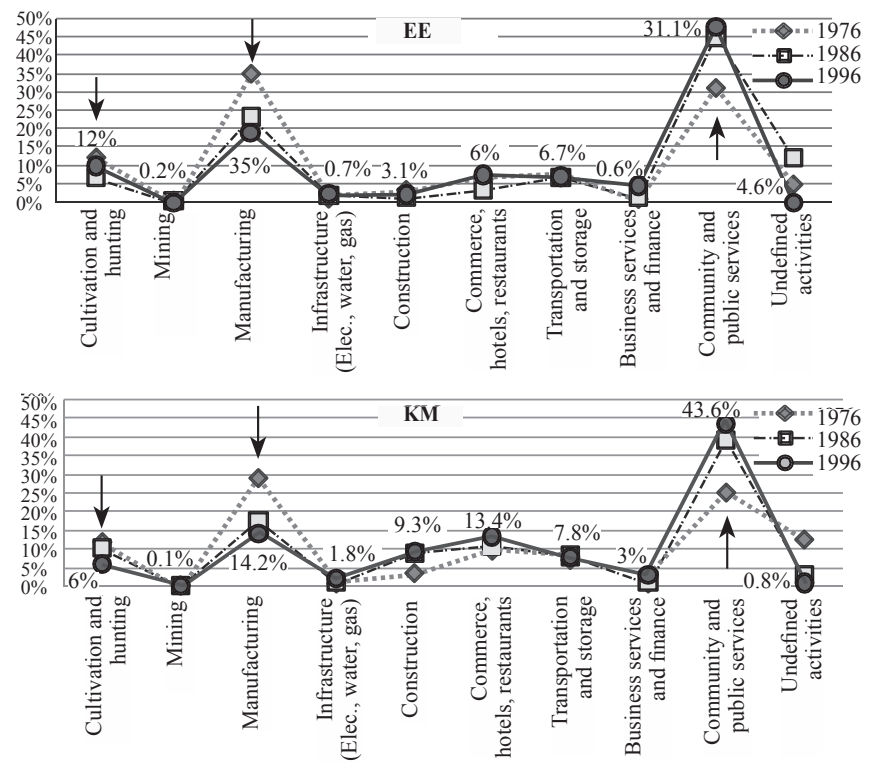

Fig. 18 Trends of Change in Economic Activities in EE and $\mathrm{KM}^{\text {9), *3) }}$

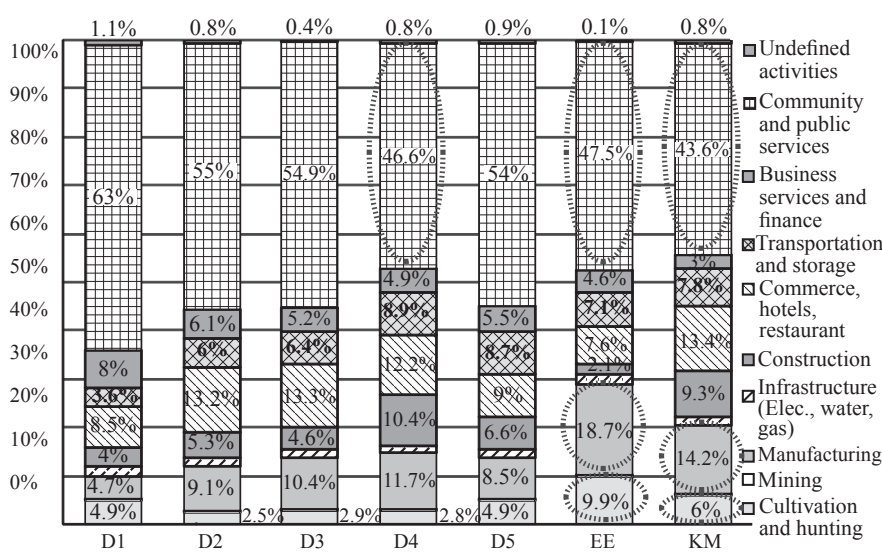

Fig. 19 Economic Activities Ratios in EE and KM Compared with Other City Divisions ${ }^{9)}$

together with closing down the main production units (e.g., the closing of the ginning factory in EE in the early 1990s) forced residents to abandon their original activities to work in jobs more related to the urban economy afforded by the city. Thus it is difficult to establish mutual economic integration between such areas and the city unless new strategies are enacted to preserve and activate their original activities, or even find new, unique ones. 


\section{NEGATIVE IMPACTS AND MAIN CAUSES}

Apart from the somewhat positive aspects of modernization, the unplanned and informal transformations that were practiced in these areas had several negative impacts on both their physical and socio-economic environments. Field observation and the results of resident questionnaires in the two study areas confirmed the existence of these negative impacts (Fig. 20) as follows.

\subsection{Impacts on the Physical Environment}

a) Incompatibility of street networks: The narrow street networks that expanded randomly (ranging between 1.5 and 4 m wide, except 1 or 2 main streets) became incompatible with modern motor transportation and even emergency vehicle access. This was noted by $44 \%$ and $85 \%$ of questionnaire respondents in $\mathrm{EE}$ and $\mathrm{KM}$, respectively, as an emerging problematic issue.

b) Deteriorating of public property: The loss of a sense of belonging to the community and the land, which had prevailed prior to encompassment, has led to more individualism ${ }^{11}$ ) in the form of caring only for one's private property and increased disregard for public property. This, together with weak local governance, has resulted in several deteriorating features in public property, which is evident in the lack of street maintenance services (noted by $51 \%$ and $46 \%$ of respondents in $\mathrm{EE}$ and $\mathrm{KM}$, respectively), the lack of garbage disposal systems (noted by $16 \%$ and $19 \%$, respectively), and the disappearance of public open spaces (noted by $33 \%$ and $73 \%$, respectively).

c) Incompatibility of block subdivisions with urban regulations: The continuous subdivision of original plots by expanding families due to the inheritance practices resulted in the formation of small property areas, some as small as $20 \mathrm{~m}^{2}$. This was noted by $64 \%$ and $85 \%$ of respondents as a problem with which they have no choice but non-compliance with construction laws when they want to construct buildings on their land.

d) Low building and infrastructure standards: Despite significant improvements in building conditions and amenities, the buildings of the two areas still lag behind those of other middle-class neighborhoods in the city. Questionnaire results showed the main emerging defects of buildings in: a lack of maintenance and facade painting $(29 \%$ and $18 \%$ of responses in $\mathrm{EE}$ and $\mathrm{KM}$, respectively), poor natural ventilation ( $9 \%$ and $5 \%$, respectively), and poor distribution of different rooms (11\% and $15 \%$, respectively). Additionally, both areas still retain a quality level gap in terms of infrastructure and services compared with those provided to the other middle-class neighborhoods of the city. This view was supported by $33 \%$ and $69 \%$ of the respondents, respectively, who complained of poor sanitation maintenance, water shortages, and occasional power interruptions.

\subsection{Impacts on the Socio-economic Environment}

a) Social conflicts: Although residents still maintain somewhat social relationships, about $66 \%$ and $75 \%$ of respondents in EE and KM, respectively, noted that these relationships became weaker following the encompassment. Further, about $4 \%$ and $35 \%$ of respondents complained of growing social conflicts due to the continuance of some rural traditional practices within the newly urbanized areas (such as animal breeding in some outdoor spaces).

b) Decreasing security: About $53 \%$ and $72 \%$ of respondents, respectively, noted that their areas' security level had decreased greatly following the encompassment period. $27 \%$ and $19 \%$ complained of increasing riots, a problem they attributed to increasing densities, fading social relations, and a

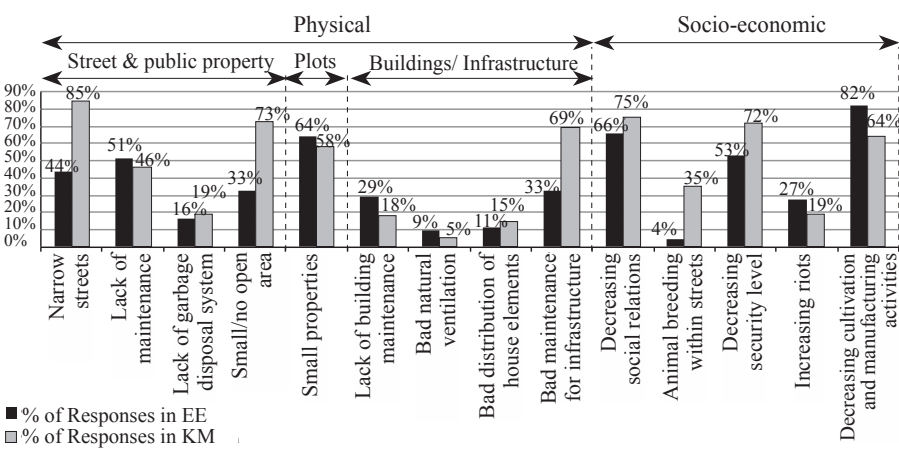

Fig. 20 Questionnaire Results for Negative Impacts of Transformations in Study Areas

lack of effective local administrative units.

c) Degrading economic activities: $82 \%$ and $64 \%$ of respondents noted decreases in cultivation and manufacturing activities as the main negative impacts of their area's transformation leading to decreased resident incomes.

Based on the above analysis, we conclude that the main causes of these informalities and their related negative impacts are:

1) Unsuitability for applying city laws: The unique characteristic of the building floor ratios in the target areas, which approach $100 \%$, makes it difficult for owners to comply with the law that requires such ratios to be $60 \%$. Furthermore, their small property sizes make it difficult for owners to widen their adjoining streets by setting their buildings back by a depth equal to half the difference between the $6 \mathrm{~m}$ required by law and the original street width; otherwise, such small-sized plots sharply decrease in their usable area; 2) Lack of separate and effective local administrative units that can manage each area's unique issues and encourage resident participation in improving their environments.

\section{CONCLUSION}

This study illustrated the different patterns of transformations that have been practiced in rural peripheral villages, specifically those subjected to urban encompassment processes within urbanized areas.

A comparative analysis based on finding similarities and differences in transformations of the two representative study areas, EE and KM of El-Minya City, was conducted. Our initial conclusions are that the areas' physical transformations had similar typologies, resulting in a) a change of their urban fabric from the traditional organic to more random linear structure, losing originally open spaces in the process of new expansion; b) new block configurations, shifting from complex to simpler linear configurations in accordance with linear irrigation systems and property edges; and c) changing building characteristics from a rural style of low-rise, traditionally-designed houses using local primitive materials to more urban style, high-rise multiapartment buildings using reinforced concrete structures. Second, we conclude that their main socio-economic transformations resulted in a) changing the community structure to a mix of rural and urban residents; b) shifting the local administrative system to district and city jurisdiction; and c) changing economic activities by increasing the percentages of those employed in city service jobs at the expense of losing the original, traditional activities.

These transformations affected the development of such areas into more informal housing settlement patterns. This conclusion was supported in our 
study through our findings of a) the incompatibility of street networks with motor transportation; b) deteriorating public property; c) the incompatibility of existing block subdivisions with city planning laws; d) the low standards of buildings and infrastructure, and also their deterioration from lack of maintenance; e) increasing social conflicts; f) weakening social relations and decreasing security levels; and g) deterioration of economic activities.

Therefore, the study found that the inappropriateness of the application of city planning and construction laws to these unique areas, together with their lack for special local administrative units, are the main leading forces for their growing informalities.

Finally, the results of our study suggest the enhancement of such areas by special local administrative units, using elected local residents to work on: a) studying the area's unique issues and identifying its problems according to their priorities; b) activating community participation when discussing solutions to the identified problems; c) establishing local bylaws that incorporate the interests of both local residents and city planners; and d) applying the needed improvement projects and monitoring their progress.

Moreover, our study raises additional focal questions to be developed in future studies: Are these transformation processes that have occurred in Egypt also occurring in other developing countries? If so, what are their similarities and differences? What are the used control strategies in similar cases? Finally, how effective can community participation be in improving such areas?

\section{Notes}

*1) Areas A, B and C are referred to Fig. 6 and 7

*2) A. constructed before the $1930 \mathrm{~s}$; B. from the late 1930 s to 1960 s; C. form the early 1970 s to 2000 s

*3) The economic activities according to 2006 are not included as they were just counted on the governorate level, not on the district level in this year.

\section{References}

1) Zhu, Y., : Insitu-Urbanization in Rural China; Case Studies from Fujian Province. Journal of Development and Change, Blackwell Publishers: Oxford, UK, Vol. 31 (2), pp. 413-434, 2000

2) Hang, M. : "Villages" in Shenzhen, Doctor engineer dissertation, Faculty of Architecture, Bauhaus University, Weimar, Germany, 2006

3) Bentinck, J.V. :Unruly Urbanization of Delhi's Fringe; Changing Patterns of Landuse and Livelihood, Doctor dissertation, Faculty of Spatial Science, University of Groningen, Netherlands, 2000

4) Brookfield, H.; et al : The City in the Village; the In-situ Urbanization of Villages; Villagers and their Land around Kuala-Lumpur, Malaysia. Published Book, New York: Oxford University Press, 1991

5) Hareedy, A. and Deguchi, A.: Rural Villages Encompassed into Urbanized Areas of Egyptian Developing Cities, J. of Architecture and Urban Design, Kyushu University,
Vol.16, pp. 47-59, 2009

6) GOPP The General Organization of Physical Planning: The General Strategic and Detailed Plan of El-Minya City, El-Minya Governorate, The Final Report, pp. 106-135, 2009

7) Elzawahry, A.: Encompassed Rural Villages into Cities; Special Concern with Greater Cairo, Un-published master thesis. Department of Architecture, Faculty of Engineering, Cairo Univ. Egyp, 1991

8) Sadek, A. : Rural Areas Encompassed within Urban Areas; A Case of Giza Governorate, Un-published master thesis, Architecture Department, Engineering Faculty, Cairo Univ., Egypt, 1989

9) CAPMAS Central Agency for Public Mobilization and Statistics office in El-MinyaEgypt : Census of El-Minya City in years “1976, 1986, 1996, 2006”, 2006

10) Hareedy, A. and Deguchi, A. : Urban Expansion Issues of Medium-Sized Egyptian Cities; The Case of El-Minya City, J. of Habitat Engineering, Vol. 1, pp. 35-49, 2009

11) Mahgoub, Yasser. : The Transformation of Traditional Rural Settlements in Egypt. The Second International Symposium in the Built Environment, "Traditional Environments in a New Millennium; Defining Principles and Professional Practice", Amasya, TURKEY, 2001

12) The General Authority for Urban Planning, Egypt :The urban planning law no.3/1982 in Egypt, 2006

13) General Organization for Government Printing Offices: Building Regulation law no. 106/ 1976 in Egypt, and its Executive Regulations, Amiria Press, Cairo, Egypt, 1996

14) El-Minya City Council, construction permission issuing office, El-Minya, Egypt, 2010

15) General Organization for Government Printing Offices: Local Administrative Law no. 43/ 1979 in Egypt, and its Illustrative Notes and Executive Regulations, Amiria Press, Cairo, Egypt, 1994

\section{和文要約}

エジプトの主要都市では急速な市街化が進行し、市街化以前には 都市の周辺の農地内に立地していた農村集落が基盤整備などを伴わ ないままに市街地に組み込まれた結果、密集地としての住環境上の問 題を生じている。本論は、エジプト中部に位置するミニヤ市(El-Minya City)を対象に、都市周辺部に立地する旧農村集落が市街化の区域内 に組み込まれていく過程での集落環境の物的変容パタンと社会経済 的な変化、及び住環境上の課題を明らかにすることを目的として実施 した調査の成果をまとめたものである。同市の北部と南部にそれぞれ 位置する異なるタイプの2つの旧集落を調査対象に、現地調査と居住 者へのアンケート調査を実施し、2つの旧集落を比較して、道路網、街 区形態、建物形態の類似性と相違を整理し、市街化に組み込まれた旧 集落の形態的特徵を明らかにした。また、住民アンケート調査と現地調 查に基づき、変容後の住環境上の課題を整理すると共に、その課題解 決には現行の一般的な土地利用規制や建築形態規制の基準の適応や 運用がもはや不適であることから、独自の住環境整備の方策が求めら れることを指摘した。

（2010年 6 月10日原稿受理，2010年11月 4 日採用決定） 